\title{
Yeniden Yeni Eğitim Sistemi
}

\author{
İRFAN ERDOĞAN"
}

irfanerdogan@istanbul.edu.tr

ORCID ID: 0000-0003-4535-4956

Öz: Türk eğitim sisteminde uzun zamandır felsefi anlamda ve yapısal olarak köklü bir değişiklik olmamıştır. Yeni Korona virüse bağlı COVID-19 hastalı̆̆ııın dünya çapında salgın hale gelmesi sonucunda okullarm kapanmastyla başlayan yeni dönemde eğitim sisteminin yapısal açıdan değişmesi öngörülmektedir. Bu anlamda Milli Ĕ̆itim Bakanlı̆̆ının (MEB) yetkilerinin azaltılması önerilmektedir. Cumhurbaşkanlığına bağh olarak yeni oluşturulan Eğitim ve Öğretim Politikaları Kurulu en üst düzeyde bir karar merci olmak durumundadır. Milli Eğitim Bakanlı̆̆ının ise bir icra birimi olarak görev yapması gerekmektedir. Milli Eğitim Bakanlığının dışında yerel otoritelerin de yerinde kararlar alabilmesinin önü açılmalıdır. Yapısal değişikliklerin dışında felsefi anlamda da bir değişim olmalıdır. Bu bağlamda da okul, öğretmen ve öğrenci gibi ana unsuların varlı̆̆ı yeniden tanımlanmalıdır. Okul öğrenme için imkân sunan kurum olmali; öğretmen rehberlik ve yönlendirme rolünü de oynamal ve öğrenci de okulun dışında her yerde her zaman herkesten öğrenmelidir. Bu şekilde okul ve öğretmen ögrenme imkânı sunan ve ögrenmeye yön veren unsurlar olarak görülmelidir. Öğrenci de kendisini klasik anlamda hep öğretilen değil öğrenen kişiler olarak kabul etmelidir. Okulun, öğretmenin ve öğrencinin bu sayede sosyal hayatta büyük krizler yaratan Covid-19 pandemisi gibi olumsuz bir gelişmenin yaşanması durumunda meydana gelecek olan yeni şartlara kolayca uyum sağlayabileceği ileri sürülebilir.

Anahtar kelimeler: Milli Eğitim Bakanlığı, Eğitim ve Öğretim Politikaları Kurulu, Yeni Ĕ̈itim

\section{Giriş}

Yeni eğitim, hep tasarlanan, değinilen dolayısıyla literatürde sıkça ele alınan bir konu olmuştur. Yeni eğitimden her dönemde var olan eğitim sistemi eleştirilerek bahsedilmiştir. Bazen halkın istek ve ihtiyaçlarını karşılamak için bir talep olarak bazen de yetkililerin gelecek hedeflerini çağrıştıran bir kavram olarak dillendirilmiştir.

Ancak eğitim genellikle, eğitimin yeni olmasına dair hedefler ve dile getirilen taleplerden kaynaklı olarak değil, toplumsal gelişmeler sonucunda değişerek yeni ol-

* Prof. Dr., İstanbul Üniversitesi, Hasan Ali Yücel Eğitim Fakültesi. 
muştur. Bir başka ifade ile yeni eğitim, hedeflendiği için değil toplumsal değişmenin bir sonucu olarak ortaya çıkmıştır. ${ }^{1}$

Uzun zamandır köklü bir toplumsal değişim yaşanmamış olacak ki eğitimde de sistemli bir dönüşüm gerçekleşmemiştir. Zorunlu eğitim süresinin arttırılması, ders programlarının ve kitaplarının değiştirilmesi gibi küçük çaplı teknik değişiklikler ${ }^{2}$ olmuştur.

Öyle görülüyor ki yakın zamanda eğitimde küresel, ulusal ve yerel ölçekte yaşanan yeni gelişmelere dayalı olarak belli açılımlar başlayacaktır. Çünkü 2019 yılının son aylarında görülen Covid-19 hastalığının bir salgına dönüşmesi sonucu oluşan gelişmeler tüm dünyada ve benzer şekilde Türkiye'de yeni bir dönemin başlamasını tetiklemektedir. Nitekim yaşamın her boyutunda belli değişiklikler olacağına dair işaretler ortaya çıkmaya başlamıştır. İnsan ve toplum hayatında, üretim sistemlerinde, hizmet sunumlarında ve daha birçok alanda gerçekleşecek etkileşim ve ilişkilerin yüz yüze olmadan elektronik araçlarla sağlanacağı bir dönem yaşanmaya başlanmıştır. Kamuda ve özelde birçok iş kolunda evden çalışılarak işleyen bir sistemin kurulacağ ifade edilmektedir. Her alanda teknoloji yoğun bir işleyişin olacağı, bu anlamda üretim, tüketim ve hareketliliğin tamamen kontrol altına alınacağı bir dönemin yaşanacağı ileri sürülmektedir. Bu emareler göstermektedir ki insanlık en köklü dönüşümlerden biriyle yüz yüzedir.

Ekonomiden sağlı̆̆a her alanda meydana gelecek olan değişime mevcut eğitim sisteminin uyum sağlaması mümkün gözükmemektedir. Zira, her yerde her zaman çalışabilmeye ve üretebilmeye dayalı esnek çalışma düzenine bir merkezden sevk ve idare edilen katı eğitim sisteminin cevap vermesi zordur. ${ }^{3}$ Pandemi gibi çabuk ve hızlı kararlar vermeyi gerektiren ani gelişmeler karşısında aşırı merkeziyetçi bir işleyişe sahip eğitim sisteminin uyum sağlaması mümkün görünmemektedir.

Dolayısıyla, salgına dayalı oluşan yeni şartların eğitimde köklü değişikliklere neden olabileceği düşünülmektedir. ${ }^{4}$ Çünkü şimdiye kadarki değişiklikler gibi münferit nitelikte atılan adımlar yeterli değildir. Dolayısıyla salgın döneminde ve sonrasında eğitimin birçok bileşeni içererek sistemli ve köklü bir şekilde değişmesi beklenmektedir. Sistemli ve köklü bir değişimin gerçekleşmesi içinse eğitimin felsefi ve yapısal boyutlarda yeniden anlamlandırılması gerekmektedir.

\section{Amaç ve Kapsam}

Bu çalışmada, eğitim sisteminde gözlenmeye başlanan ve gözlenebilecek olan bu muhtemel değişiklikler hakkında öngörü ve değerlendirmelerin sunulması amaç-

\footnotetext{
${ }^{1}$ İ. Hakkı Baltacıoğlu, Talim ve Terbiyede İnkılâp, İstanbul: Kanaat Kitabevi, 1927.

${ }^{2}$ Son çeyrek yüzyıl içinde gerçekleştirilen zorunlu eğitim süresinin kesintisiz olarak sekiz yıla çıkarılması (1998), lise öğretiminin dört yıla çıarılması (2003), zorunlu eğitimin 4+4+4 şeklinde 12 yıla çıkarılması (2012), Fatih projesi (2014), liselere geçiş ve üniversiteye geçiş sınavlarının birçok kez değiştirilmesi münferit sayılabilecek diğer değişiklik örnekleridir.

${ }^{3}$ Lee G. Bolman ve Terrence E. Deal, Modern Approaches to Understanding and Managing Organizations, Oxford: Jossey Bass Pub., 1990.

${ }^{4}$ Marko Teräs vd., "Post-Covid-19 Education and Education Technology 'Solutionism': A Seller's Market", Postdigital Science and Education, 2/3 (2020), s.863-878.
} 
lanmaktadır. Öncelikle mevcut karar verme ve uygulama mekanizmasının tıkandığ 1 varsayılarak yeni bir idari sistem önerilecektir. İkinci olarak da mevcut eğitim felsefesinin de işlevsizleştiği düşünülerek okul, öğretmen ve öğrenciyle ilgili pandemi koşullarının yarattığı sosyolojik değişim ikliminde yeni bir eğitim felsefesi sunulacaktır.

Bu çalışmada sunulan düşünce ve önerilerle, salgın ve sonrasındaki dönemde eğitimin kaçınılmaz bir şekilde değişmeye ihtiyaç duyduğu ve duyacağı düşünüldügünde bu hususta doğru adımların atılmasına ışık tutmak amaçlanmaktadır.

\section{Yeniden Yeni Bir Eğitime Doğru}

Eğitim sisteminin yenileştiği sıkça ifade edilmiş olsa da yapısal ve felsefi açlardan köklü değişikliklerin gerçekleşmediği gözlenmektedir. ${ }^{5}$ Geçmişten bugüne eğitimde değişiklikler yapıldığı ileri sürülmüş ve bunun çeşitli örneklerinin etkileri gözlenmiş olmakla birlikte ${ }^{6,7}$, eğitimde gerçek anlamda öğrencilerin gelişim ve öğrenme olanaklarını sistemli bir biçimde artırıp destekleyecek bir yenileşmenin iyileştirici izlerine rastlandığını söylemek güçtür. Bunun temel nedeni, eğitim hakkında politika geliştiren ve karar veren mercilerden bağımsız olarak, aslında uzun zamandır toplumsal düzende, sosyal hayatta ve kültürde eğitimin mevcut yapı ve anlayışının köklü olarak değişmesini sağlayacak nitelikte önemli bir gelişmenin gerçekleşmemiş olmasıdır. Zira sosyal bir olgu olan eğitim dişarıdan müdahale ile değiştirilen değil, sosyal şartların etkisiyle kendiliğinden değisșen bir sistemdir. ${ }^{8}$

Dünya Sağlık Örgütünün 2020 yılı başlarında ilan ettiği salgın (pandemi) koşulları ile birlikte hayatın her alanında hissedilen yeni bir dönemin başladığı söylenebilir. $\mathrm{Bu}$ süreç, kaçınılmaz olarak eğitimin de belli yönleriyle değişeceğine işaret etmektedir. Nitekim salgının toplumda ve kamu hizmetlerinin sunulmasında yarattığı krizlerden dolayı eğitimde de belli tıkanmalar yaşanmaya başlamıştır. Dünya genelinde okullar kapanarak yüz yüze gerçekleşen eğitim büyük ölçüde kesintiye uğramıştır. ${ }^{9}$ Buna dayalı olarak ortaya çıkan eğitim ve öğrenme açığı birçok ülkede olduğu gibi Türkiye'de de uzaktan öğretim yoluyla giderilmeye çalışılmaktadır.

Ancak okulların kapalı kalmasının özellikle halihazırdaki dezavantajlı olanlar başta olmak üzere öğrencilerin öğrenmelerini olumsuz yönde etkilediği rapor edilirken ${ }^{10}$ (Moldonado ve De Witte, 2020), eğitim sistemlerinin derslerin yapılmadığı sürelere karşı belli adımlar atılırsa dayanaklı hale gelebileceği öngörülmektedir. Diğer yandan, salgın gibi kriz durumlarının eğitim sisteminde teknolojiye olan bağımlılığı artırarak yönetilmesinin esas çare olmadığı, bunun yerine yeni durumun bir

\footnotetext{
${ }^{5}$ İrfan Erdoğan, Eğitimde Değiş̧im Yönetimi, Ankara: Pegem Yayınları, 2012.

${ }^{6}$ Firdevs Melis Cin, Ecem Karlıdağ Dennis ve Zeynep Temiz, "Capabilities-Based Gender Equality Analysis of Educational Policy-Making and Reform in Turkey.", Gender and Education, 32/2 (2020), s.244-261. (erişim 20.09.2020)

7 İsmail Güven, “The 4+ 4+ 4 School Reform Bill and The Fatih Project: Is It a Reform?”, Ilkogretim Online, 11/3 (2012), s.556-577. (erişim 16.09.2020)

${ }^{8}$ Baltacioğlu, Talim ve Terbiyede İnkılâp.

9 "COVID-19 Educational Disruption and Response", UNESCO, erişim 11 Ağustos, 2020, https://en.unesco.org/covid19/educationresponse.

${ }^{10}$ Joana Maldonado ve Kristof De Witte, "The Effect of School Closures on Standardised Student Test." FEB Research Report Department of Economics, 2020. (erişim 16.09.2020).
} 
firsat olarak görülerek eğitim sistemlerinin yenilenmesi gerektiği de ileri sürülmüştür. ${ }^{11}$

Pandemi sürecinin bir-iki yıl gibi bir süreyi kapsayacağ 1 tahmin edilmektedir. ${ }^{12}$ İşte bu çalışmada pandemi ve sonrası dönem için mevcut eğitim sisteminin ve eğitim algısının şartlar ve ihtiyaçlar gözetilerek değişmesine yol aç3acak belli başlı açılımlar sunulmaktadır. Bu manada okul, öğretmen ve öğrenciyle ilgili yeni anlamlandırmalar yapılarak eğitimin özellikle sevk ve idare açısından nasıl sunulacağına dair bir çerçeve sunulmaktadır.

Bu doğrultuda eğitimde yeni dönemde olması gereken değişiklikler yapısal ve felsefi olmak üzere iki boyutta ele alınacaktır. Yapısal boyut sistemin varoluş amaçları doğrultusunda merkezi ve yerel otoriteler arasındaki yetki ve sorumlulukların dağllımıyla ilgilidir. Felsefi boyut ise sistemin varoluş temeli olmakla birlikte okul, öğretmen ve öğrenci gibi ana unsurlara dair yapılan anlamlandırmayı ifade etmektedir.

\section{Yapısal Adımlar}

Türk Eğitim Sisteminin işleyişiyle ilgili üst, orta ve alt olmak üzere üç ana kademe bulunmaktadır. Üst kademe temel politikaların geliştirildiği, orta kademe bu politikaların tabanda hayata geçirilmesi için aracı çalışmaların yapıldığı ve alt kademe de uygulamaların gerçekleştirildiği düzeyi ifade etmektedir. ${ }^{13} \mathrm{Bu}$ çerçeveye göre üst kademeyi Cumhurbaşkanlığı Eğitim ve Öğretim Kurulu ${ }^{14}$ oluşturmaktadır. Orta kademeyi Milli Eğitim Bakanlığı, alt kademeyi de eğitimle ilgili yerel düzeydeki birimler temsil etmektedir.

Eğitim ve Öğretim Politikaları Kurulu ulusal düzeyde gerçekleştirilecek olan eğitim çalışmalarıyla ilgili en üst düzeydeki karar merciidir. Dolayısıyla eğitimin amaçları ve geleceğiyle ilgili kararlar bu düzeyde alınmalıdır. Eğitimin millilik vasfı bu kurul sayesinde korunmalı ve sağlanmalıdır. Eğitime dair en üst düzeyde kararlar verecek olan bu kurul sadece Milli Eğitim Bakanlığına değil diğer bakanlıklara ve ilgili birimlere de ışık tutmalı ve yön vermelidir. Örneğin Kültür ve Turizm Bakanlığ ${ }^{-}$ nın veya Sağlık Bakanlığının eğitimle ilgili olabilecek çalışmalarına bu üst kurul yön vermelidir.

Ancak eğitim sisteminin işleyişi içinde statüsü en yüksek olan bu kurulun eğitimin her boyutuna hâkim olacak şekilde yapılanması gerekmektedir. Dolayısıyla belli sayıdaki üyelerden oluşan bu kurulun eğitimle ilgili oluşturulacak politikalar ve alınacak kararlar için çalışmalar yapmak üzere çeşitli birimlerle ve bürolarla da desteklenmesi önemlidir. Diğer taraftan bu kurulda alınacak kararlarla ve oluşturulacak politikalarla ilgili son kararı verme pozisyonunda olan üyelerin seçimi için

\footnotetext{
${ }^{11}$ Teräs, “Post-Covid-19 Education and Education Technology 'Solutionism': A Seller's Market.”

${ }^{12}$ Roy M. Anderson vd., "How Will Country-Based Mitigation Measures Influence The Course of The COVID-19 Epidemic?”, The Lancet, 395/10228 (2020), s.931-934. (erișim 14.08.2020)

${ }^{13}$ Ziya Bursalıŏlu, Okul Yönetiminde Yeni Yapı ve Davranış, Ankara: Personel Eğitim Merkezi, 1994.

${ }_{14}$ Eğitim ve Öğretim Kurulu 2018 yılında yapılan anayasa değişikliği uyarınca yürürlüğe giren yeni Cumhurbaşkanlığı Hükümet Sistemi kapsamında oluşturulmuştur.
} 
de bir sistem geliştirilmek durumundadır. Ayrıca kurul üyelerinin temsil ve uzmanlık niteliğinin ön planda tutularak seçilmesi de özen gösterilmesi gereken bir husustur.

Yeni sistem gereğince Milli Eğitim Bakanlığının bir karar merci değil uygulayıcı bir birim olması öngörülmektedir. Bu doğrultuda MEB'in ülke genelinde yürütülen belli çalışmaları sürdüren icracı bir kademe olması beklenmektedir. Dolayısıyla Milli Eğitim Bakanlığı ülke genelindeki eğitimle ilgili hususlarda Cumhurbaşkanlığınca geliştirilen politikaları hayata geçirmekle görevli olmalıdır.

Yeni sistemin gereği olarak öğretmen istihdamıyla ilgili yetki MEB yerine, yerel birimlere bırakılmalıdır. Okulların açılış ve kapanış programı aynı şekilde yerel birimlere devredilmelidir. MEB okullarda sunulan müfredatın tamamını değil, ancak eğitimin millilik vasfını karşılanmasını sağlayan somut bir kısmını hazırlayarak takip etmelidir. Tüm bu işleyişlerde MEB planlayıcı, hazırlayıcı ve uygulayıcı olmalidir.

MEB'in ülke geneli için bağlayıcı kararlar almasının pek işlevsel olmadığı salgın sürecinde kendini gösterdi. Nitekim okulların tüm ülkede kapanması ve bir müddet sonra açılmaya çalışılmasının verimsiz olduğu gözlendi. Oysa okulların açılması ve kapanması ile ilgili uygulamalar, yetki ve sorumlulukların üst kademede değil de icracı-uygulayıcı alt kademelerde olduğu birçok ülkede daha etkili ve verimli olmuştur. Zira okulların açılmasıyla ilgili kararlar birçok ülkede bölgelere göre değişmiştir. ${ }^{15}$ Dolayısıyla o ülkelerde eğitim ve öğrenme adına telafi edilemeyecek ölçüde açıklar olmayabileceği değerlendirilmektedir.

Bu nedenle Milli Eğitim Bakanlığı'nın ülke genelinde icra ettiği görevler eskisi gibi devam etmemeli, bu görevlerin önemli bir kısmı üst ve alt kademelere dağıtılmalıdır. Bu değişiklik hem yeni yürürlüğe giren Cumhurbaşkanlığı Hükümet Sistemi gereğince hem de salgın ve gelecekte karşılaşılabilecek benzer sosyal krizlerin ortaya çıkardığı koşullar karşısında daha işlevsel bir sisteme sahip olmak için önemli bir gerekliliktir.

Yeni dönemde eğitime dair icra faaliyetlerinin tamamının Milli Eğitim Bakanlı̆̆ tarafından yürütülmesi beklenmemelidir. Bilhassa eğitimin organizasyonu ve sunulmasıyla ilgili yerel düzeyde de sorumluluklar alınmalıdır. Bu anlamda yerel düzeydeki mülki amirlerin ve belediyelerin de eğitimle ilgili yetki ve sorumlulukları olmalıdır. İl ve ilçe gibi yerel düzeylerdeki yetkili otoritelerin eğitimle ilgili icraat yapma yetki ve sorumlulukları olmalıdır. Örneğin öğretmen istihdamıyla ilgili yetki MEB'de olmamalı, bu yetki yerel birimlere bırakılmalıdır. Okulların açılış ve kapanış programlarının belirlenmesiyle ilgili yetki aynı şekilde yerel birimlere devredilmelidir. Okullarda sunulan müfredat da belli oranlarda ve boyutlarda yerel otoritelerce hazırlanmalı ve takip edilmelidir.

$\mathrm{Bu}$ şekilde eğitim, ulusal olduğu kadar yerel bir husus olarak da ele alınmış olur. Bu sistemde MEB'in yerel düzeydeki eğitim öğretim faaliyetleriyle ilgili fonksiyonu

15 "COVID-19 Educational Disruption and Response". 
da şu şekilde özetlenebilir. MEB, ulusal eğitimin güvencesi olacak şekilde belli çalışmalara rehberlik etmeli ve bu çalışmaları takip etmelidir. Milli eğitimin temel amaçlarının gerçekleşmesiyle ilgili tedbirleri alarak gerekli yönlendirme ve denetimleri yapmalıdır. Ayrıca Bakanlık bütçesinden yerel düzeyde ayrılan kaynakların etkili bir şekilde dağıtılmasını sağlamalıdır.

Eğitimle ilgili yerel düzeyde bu makalede işaret edilen icraatları yapmak ve kararları almak için yeni bir yerel örgütlenmeye gidilmek durumundadır. Bunun için kararların nasıl alınacağı icraatların nasıl yapılacağı, bu hususlarda kimlerin ve hangi birimlerin yetki ve sorumluluk sahibi olacağı, bu birimlerin nasıl oluşturulacağı ve yetkili otoritelerin nasıl seçileceği belirlenmelidir. Bu şekilde önerilen yeni eğitim sistemi gereğince eğitimle ilgili yeni bir yerel eğitim teşkilatı oluşturulmalıdir.

Oluşturulacak yeni yerel eğitim teşkilatının bilhassa salgın gibi ani ortaya çıkan yeni koşullar karşısında daha işlevsel olacağı beklenebilir. Özellikle okulların açılması, gerekirse kapanması ve benzeri işleyişlerle ilgili olarak daha etkin, hızlı ve ihtiyaca yönelik kararlar alınabilir.

Böyle bir idari yapılanma yani bir takım yetki ve sorumlulukların yerelde olması, toplumla okulun kaynaşma imkânlarını artırır. Toplumun sunulan eğitimi daha çok sahiplenmesi mümkün olur. Okulların içinde bulunduğu çevrenin ihtiyaçlarına daha etkin bir şekilde cevap vermesi sağlanmış olur. Böylece okul, aile ve toplum arasındaki aidiyet duygusunun da gelişeceği ifade edilebilir. ${ }^{16}$

Burada Milli Eğitim Bakanlığının eğitimle ilgili yetki ve sorumluluğun belli ölçülerde yerel düzeylere aktarılmasıyla ilgili bir tez ileri sürüldü. Ancak bu tezin hayata geçmesi için kamu düzeninde, mevzuat ve yönetmeliklerde yeni düzenlemeler yapılması gerektiği de göz önünde bulundurulmalıdır.

\section{Felsefi Açılımlar}

Felsefe doğruyu bulma yolunda düşünsel bir çalışmadır. Felsefe eleştiridir, deney ve gözleme dayanan bilimsel veriler üzerinde düşünmektir, üzerinde henüz belirli bir bilginin bulunmadığı konularda kurgular yapmaktır. Kısacası bir düşünme sürecidir. Bir bilgelik hali olarak da tanımlanan bu sürecin sistemli, tutarlı ve bütüncül olması esastır.

Aşağıda yeni eğitimle ilgili yukarıda sunulan yapısal boyutu anlamlı kılacak düşünsel ilişkilendirmeler sunulacaktır. Bir başka ifade ile yeni eğitimin felsefi zemini çeşitli boyutlarda irdelenecektir. Bunun için yukarıda sunulan yeni eğitim çerçevesi ile uyumlu olacak şekilde okul, öğrenme merkezi, öğretmen ve öğrenci bağlamında yeni anlamlandırmalar ve ilişkilendirmeler yapılacaktır.

Şimdiye kadar ve halen geçerli olan sistemde okullar varlığını Milli Eğitim Bakanlığının belirlediği çerçeveye göre sürdürmekteydi. Ancak okulların doğrudan MEB'e bağlı olmasının 2020 yılında ilan edilen salgın sürecinde işlevsel olmadığ 1 açık bir şekilde görüldü. Okulların salgın nedeniyle ülke genelinde kapatılması ile

${ }^{16}$ William H. Clune ve Paule A. White, School-Based Management, CPRE Research Report Series, 1988. 
ilgili olarak alınan karar uygulanırken bu kararın sorun yaşanmayan bazı bölgelerin mevcut ihtiyaçlarının karşılanması açısından işlevsiz kaldığı gözlendi.

$\mathrm{Bu}$ nedenle yeni sistemde okullar MEB'e bağlı olduğu kadar yerel otoritelere de bağlı olmalıdır. Yani okullardaki işleyiş̧e ilişkin yerel düzeyde de kararlar ve sorumluluklar alınabilmelidir. Bu anlamda okulla ilgili harcamalar hem merkezi bütçeden hem de yerel bütçeden sağlanmalıdır. Okulun idaresi ve öğretim kadrosu belli şartlara uymak koşuluyla yerel birimlerce belirlenmelidir. Bu şekilde yerel yetkililer MEB'in politikalarını dikkate almakla birlikte içinde yaşanılan bölgelerin gerçeklerini de dikkate almak durumunda kalırlar.

$\mathrm{Bu}$ anlamda okulları birer toplum merkezi olarak da görmek gerekir. Bunun için okullar içinde bulunduğu toplumun ihtiyaçlarını karşılayabilme kapasitesine ve esnekliğine sahip olmalıdır. ${ }^{17}$ Örneğin okullarda tiyatro, konser, konferans, kurs ve sergi gibi faaliyetler yürütülebilmelidir. Bu şekilde öteden beri önemli bir ilke olarak dillendirilen hayata hazırlayan okul inancının yerini hayatın yaşandığı okul düsturu almalıdır.

Okul bu hale dönüştüğünde bildiğimiz anlamdaki eğitim öğretim takviminin ötesinde bir işleve sahip olur. Bu şekilde sadece ders planlarına göre değil sürekli açık olmak durumunda kalır. Bu arada yeni sistem gereğince okullar sadece derslerin işlendiği yerler değil aynı zamanda kendi çapında üretim yapılan atölyeler olarak da işlev görmelidirler. Özellikle meslek liseleri gerçek hayatla ilişkili belli üretimlerin yapıldığı fabrikalar olabilir. Bu eğitimin eğitim için değil üretim için yapılmasını sağlar. Okula dair tüm bu anlamlandırmalar okulun sadece bir öğretim yeri değil bir öğrenme merkezi olmasını sağlar. ${ }^{18}$ Okulların bu hale dönüşmesi birtakım kararların okul düzeyinde alınabilmesi için birtakım düzenlenmelerin yapılmasını gerektirir. Bu da temelde okulların daha çok özgürleşmesi demektir.

Eğitimin sadece okullarda gerçekleşmesi çağın dinamizmi ve değişkenliği açısından yetersizdir. Okullar belli ölçülerde esnetilse dahi hızlı ve ani değişikliklere uyum sağlamada zorlanır. Bu nedenle yeni dönemde okullara göre daha dinamik ve esnek bir tarzda eğitim sunan öğrenme merkezlerinin de varlığına ihtiyaç duyulmaktadır. Öğrenme merkezlerinin temel özelliği okul çağındaki çocuk ve gençler için onların arzu ettiği ve ihtiyaç duyduğu alanlarda öğrenme imkânları sunan yerler olmasıdır. Bu yerlerin sadece akademik yönelime cevap vermesi yeteri değildir. Aynı zamanda çocukların sosyal ilişkiler kurabilmelerine uygun olması ve bunun için firsatlar sağlaması gerekir. Toplum-Öğrenme merkezlerinin şayet çok güçlü ve yeterli olursa temel özelliği okul olmadığı halde okul işlevini yerine getirebilmesidir.

Toplum-Öğrenme merkezleri sayesinde eğitimin düzlemi okulların sınırları dışına taşmış olur. Bu merkezler okulların biçimselleşmesi karşısında oluşan eğitim durağanlığını da büyük ölçüde kırabilir. Okulda öteden beri sağlanamadığ len doğal eğitim de buralarda daha etkin bir şekilde gerçekleşebilir. Bu yerler ayrıca

${ }^{17}$ Kevin Ronan ve David Johnston, Promoting Community Resilience in Disasters: The Role for Schools, Youth, and Families, NewYork: Springer Science \& Business Media, 2005.

${ }^{18}$ Robert B. Barr ve John Tagg, "From Teaching to Learning: A New Paradigm for Undergraduate Education", Change: The Magazine of Higher Learning, 27/6 (1995), s.12-26. (erişim 10.08.2018). 
daha farklı yaş gruplarına ve yetişkinlere de hitap edebilme kapasitesine dayalı olarak eğitimin daha ideal bir şekilde gerçekleştiği mecralar olabilir. Bu sayede toplum merkezleri, katı işleyişi, sınırları ve kuralları ile bilinen öğretim süreçlerinin yerine ikame edilebilir.

Mevcut eğitim sistemimin yaygın öğretmen algısı MEB'e bağlı olarak beklenen icraatları yapmaya dayalıdır. Buna göre öğretmen, üst düzeydeki yetkililerin hazırladıkları plan doğrultusunda çalışan kişiler konumundadır. Yetkililerin aldığı kararları uygulayandır. Öğretmenin yukarıdan gelen talimatlar doğrultusunda görev yapmasının pek işlevsel olmadığı salgın sürecinde açık bir şekilde gözlemlendi. Örneğin dünyada, özellikle gelişmekte olan ülkelerdeki öğretmenlerin merkezi otoritenin beklentilerinin ötesinde, öğrencilerinin öğrenme olanaklarından faydalanabilmesi için inisiyatif kullandıkları görüldü. ${ }^{19}$

Yeni eğitim sisteminde öğretmen bağlı olduğu birimlerin izinde yürümenin d1şında kendi kendine de kararlar alıp icraatlar yapacak kişiler olarak algılanmalıdır. Öğretmeni olduğu çocuk ve gençler için gerektiğinde kendi başına kararlar verme ve uygulama yapma sorumluğuna sahip olan kişiler olarak görülmelidir. Bir başka ifade ile öğretmenler, bulunduğu hiyerarşik yapı içinde sadece tanımlanmış görevlerini yapan değil, aynı zamanda gerektiğinde inisiyatif kullanan kişiler olarak değerlendirilmelidir. Sadece öğreten değil aynı zamanda öğrenme imkânları sunan eğitimciler olarak tanımlanmalıdır. Öğretmenliğe dair algının bu şekilde olması onların zamanın, mekânın ötesinde her türlü olumsuzluklara rağmen öğretmen olmalarını sağlar. ${ }^{20}$

Bu bağlamda öğretmenin yeni eğitim sistemine yönelik bütüncül bir yaklaşıma sahip olması ve öğrencilerin gelişim ve öğrenme ihtiyaçlarının karşılanmasında paydaşlar arası işbirliğini sağlamayı üstlenmesi önemlidir. Öyle ki alan uzmanlığının dışında ilgili olduğu eğitim kademesi hakkında da bilgi sahibi olması gerekir. Eğitim ve öğretim faaliyetlerinin esnekleşeceği dikkate alınırsa öğretmenlerin danışmanlık ve rehberlik görevini daha etkin bir şekilde yerine getirmesi gerekir. ${ }^{21}$

Yeni eğitime dair ileri sürdügümüz kurguya göre öğretmenlerin atanmasında yerel birimlerin de etkin olması gerektiğini dile getirmiştik. Bu düşüncenin hayata geçmesi öğretmenleri ve benzer şekilde stajyerlik yıllarını tamamlamaya ihtiyaç duyan aday öğretmenleri yerel düzeyde de hesap verebilir hale getirecek, aynı zamanda salgın gibi öngörülemez şartlarda dahi öğretmen açı̆̆ının ve öğretmen yetiştirmenin bir arada sağlanmasına hizmet eden çözümler üretmek mümkün olabilecektir. ${ }^{22}$ Böylece öğretmenlerin içinde yaşadığı toplumla daha fazla iç içe olmaları ger-

\footnotetext{
19 "How Teachers Are Leading Efforts to Ensure Learning Never Stops during COVID-19 Education Disruption”, UNESCO, erişim 26 Eylül, 2020, https://en.unesco.org/news/how-teachers-are-leading-effortsensure-learning-never-stops-during-covid-19-education.

${ }^{20}$ Doğan Cüceloğlu ve İrfan Erdoğan, Öğretmen Olmak: Bir Can'a Dokunmak, İstanbul: Final Kültür Sanat Yayınlar1, 2014.

${ }^{21}$ G. Moss vd., "Primary Teachers' Experience of the COVID-19 Lockdown-Eight Key Messages for Policymakers Going Forward”, London: UCL Institute of Education, 2020, (erişim 12.07.2020).

${ }^{22}$ Loretta Mason Williams vd., "Addressing Shortages of Educators in an Uncertain COVID-19 Landscape: Viewing Teacher Candidates As Assets”, Center on Great Teachers and Leaders, 2020, (erișim 20.08. 2020).
} 
çekleşmiş olacaktır. Çünkü öğretmenler, kendilerinin istihdamında etkili olan yerel birimlerle de ilişkili olmak durumunda kalacaklardır.

Öğretmenlerin önerilen yeni eğitimde hep görev alan değil kendi kendisine görev veren kişiler olması beklenmektedir. Nitekim imkânların görece daha sınırlı olduğu bölgelerde bile öğretmenlerin, salgın döneminde artan iş yükü ve sorumluluklarını ögrencilerin bireysel öğrenme ihtiyaçlarını gözeterek yürüttüğü örneklere rastlanmaktadır. ${ }^{23}$ Dolayısıyla kendi dışında başkaları tarafından hazırlanan kalıplara göre öğretmenlik yapmanın değil kendinden hız alarak kendi kararları ve imkânları ile öğretmen olmanın esas olması öngörülmektedir.

Yeni eğitim sisteminde öğrenci olmak demek okulun ve müfredatın dışında da var olmak demektir. Bu anlamda öğrencinin kendisini sadece okulla ve müfredatla özdeş görmek yerine her yerde, her zaman herkesten öğrenebileceğine inanan bir bakış açısına ihtiyaç duyacağı söylenebilir. Zira, öğrenci olmak okulla sınırlı olarak değerlendirildiğinde değişimin şartlarına uyumdan söz edilemez. Bu nedenle öğrencilik evde, sosyal hayatta da gerçekleştirilmelidir.

Bu makalede sunulan tezler yeni bir öğrenci olma kültürü gerektiriyor. Zira kendi öğrenmesi ile ilgili daha fazla sorumluluk alacak olan öğrencinin buna dair bir kimlik inşa etmesi gerekir. Bu kültür sayesinde öğrenciler için klasik öğrenme mekânları olarak okulların salgın gibi belli koşullara dayalı olarak kapalı olması onların bir şey öğrenmesi için engel teşkil etmez. Çünkü öğrenme sorumluluğunu üzerine alan öğrenciler için okul kapalı olsa bile her yer öğrenme için birer firsat olur. Aynı şekilde ders programlarının sıkıştıııldığı zaman dilimlerinin dışındaki zamanlar da öğrenme için kullanılır. Nitekim, akademik öz disiplini yüksek olan ve salgın şartlarına bir tatil dönemi değil yeni bir çalıma düzeni olarak yaklaşan öğrencilerin endişe yaşama olasılıklarının daha az olduğu gözlenmiştir. Bununla birlikte, bu öğrencilerin, akademik ilgi ve katılımlarının daha yüksek olduğu bildirilmektedir. ${ }^{24}$

Burada ifade edilen düşüncelere göre öğrencilerin öğretilen kişiler olarak algılanmasına dayalı yaygın anlayış geride kalacak; öğrenen kişiler olarak algılanması daha yaygın hale gelecektir. Öğrenciliğin klasik okul, müfredat, ders gibi kalıplarının ötesinde zaman ve mekân ötesi bir düzleme yayılması gerçekleşecektir. Böylece uzun zamandır bir statü haline gelen öğrencilik bir varoluş sürecine dönüşecektir. Tüm bu yeni anlamlandırmalarla öğrenciliğin daha çok özgürleşeceği bir dönem beklenmelidir.

\section{Sonuç, Tartışma ve Öneriler}

Bugünün Sonuç olarak özde Milli Eğitim Bakanlığı’nın rolünün değişmesini öngören yeni sistem önerisi aslında eğitimin özgürleşmesiyle ilgili bir taleptir. Salgın

\footnotetext{
${ }^{23}$ Ute Kaden, "COVID-19 School Closure-Related Changes to the Professional Life of a K-12 Teacher", Education Sciences, 10/6 (2020), s.165. (erişim 03.07.2020).

${ }^{24}$ Stephan Gerhard Huber ve Christoph Helm, "COVID-19 and Schooling: Evaluation, Assessment and Accountability in Times of Crises: Reacting Quickly to Explore Key Issues for Policy, Practice and Research with The School Barometer", Educational Assessment, Evaluation and Accountability, 32 (2020), s.237-270, (erișim 15.06.2020).
} 
süreci gösterdi ki; eğitimin ülke genelinde sadece Milli Eğitim Bakanlığının karar ve uygulamaları ile sürdürülmesi mümkün gözükmemektedir. Devletin eğitim sunma sorumluluğu kadar bireyin kendi eğitiminin peşinde olması gerektiğinin de ne kadar önemli olduğu ortaya çıkmıştır. Burada sunulan düşünceler bireyin kendi eğitimini almada tercihler yapabileceği bir işleyişe işaret etmektedir. Aynı şekilde toplumun da daha çok sorumluluk almasına dikkat çekilmektedir.

İleri sürdüğümüz yeni sistem Milli Eğitim Bakanlığının yetki ve sorumluluklarının yeniden ele alınmasını gerektirmektedir. Yeni sistemle birlikte asıl yaşanacak dönüşüm eğitimin öğrenme merkezli bir düzleme oturtulması olacaktır. Zira önerilen sistemin yapısı ve işleyişi öğretme üzerine değil öğrenmeye katkı sağlayacak şekilde oluşturulmuştur.

Önerilen sistemde öğrenme faaliyetlerinin planlanması ve tasarlanması tek bir merkezden belirlenmeyecektir. Aynı şekilde öğrenmenin okulun dışında daha geniş bir düzlemde gerçekleşmesi kurgulanmaktadır. Kurgulanan sistemde öğrenci kendi öğrenmesi için daha özgür olacak ve daha fazla sorumluluk alacaktır. Okullar öğreten değil imkân sunan yerler olacaktır. Öğrenme sadece okulda olmayacak; okul dişı mekânlarda da gerçekleşecektir.

İşleyişin bu şekilde olması eğitimle ilgili yetki ve sorumlulukların geniş bir yelpazeye yayılması demektir. Merkezde toplanan yetki ve sorumlulukların dağıtılmasıyla ilgili olarak eğitimin milliliğinin zayıflayacağına dair bir endişe ortaya çıkarabilir. Ancak önerilen sistemle ne yerel otoritelerin tek yetkili olacağı ne de merkezi otoritenin ortadan tamamen kalkacağı beklenmemelidir.

Sonuç olarak yeni eğitim sisteminde Cumhurbaşkanlığına bağlı olarak faaliyet gösteren Eğitim ve Öğretim Politikaları Kurulunun milli eğitim siyasetinin belirlenmesi ve bunun hayata geçmesi için gerekli tedbirleri alması beklenirken Milli Eğitim Bakanlığının da adı geçen kurulun belirlediği politikaları hayata geçirmesi yani “icra” yapması beklenmektedir. Diğer taraftan eğitimle ilgili icra çalışmalarının bir kısmının da yerel düzeyde yerel otoritelerin yetki ve sorumluluğunda gerçekleşmesi tasarlanmaktadır. Yerel düzeydeki yetkili kurumların yerel düzeyde bazı teknik kararları da alması öngörülmektedir.

Öngörülen bu sistemin iyi işlemesi ve başarılı olması için Eğitim ve Öğretim Politikaları Kurulunun üst düzey kararlar verebilecek ve ulusal politikalar geliştirebilecek şekilde ileri düzeyde liyakatli üyelere sahip olması önemlidir. Bu durumda icracı olması öngörülen Milli Eğitim Bakanlığı kadroları da uygulayıcı olacak şekilde uzmanlık niteliğine sahip olmalıdır. Sistemin tabanını oluşturan yerel düzeydeki birimlerin de eğitime dair belli konularda belli sınırlar içinde kararlar alabilme becerisine ve uygulamalar yapabilme kapasitesine sahip olması gerekmektedir.

Yetki ve sorumlulukların üç düzeyde dağıtılmasını esas alan bu sistemin toplumsal hayatta yaşanabilecek ani ve köklü değişikliklere karşı işlevsel olacağı düşünülmektedir. Bu anlamda son yaşanan salgın probleminin yetki ve sorumlulukların ağırlıklı olarak bir merkezde toplanmasını sağlayan sistemde yarattığı tıkanmanın tekrar aynı ölçüde yaşanmayacağı ileri sürülebilir. 
Yapıyla ilgili tasarlanan bu değişikliklerden sonra öğretmeye bağımlı eğitim anlayışının öğrenme odaklı bir yaklaşıma dönüşmesinin de eğitimin salgın gibi şartlarda yani her halükarda sürdürülebilirliğini ve işlevselliğini mümkün kılması beklenmektedir.

Dolayısıyla bu makalede önerilen sistemin Eğitim ve Öğretim Politikaları Kurulu, Milli Eğitim Bakanlığ ve yerel otoriteyi içeren unsurların her birinin belli oranlarda yetkilendirilmesinin dışında okulun, öğretmenin ve öğrencinin, öğrenmenin sağlanmasına dayalı bir bakış açısıyla tanımlanmasıyla son yaşanan Covid-19 pandemisi gibi sosyal hayatta büyük krizler yaratan her türlü olumsuz gelişmelere karşı dayanaklı olacağı söylenebilir.

\section{Kaynakça}

Anderson, Roy M., Hans Heesterbeek, Don Klinkenberg ve T. Déirdre Hollingsworth. "How Will Country-Based Mitigation Measures Influence the Course of the COVID-19 Epidemic?”. The Lancet. 395/10228 (2020): 931-934. https://www.thelancet.com/journals/lancet/article/PIIS01406736(20)305675/fulltext?utm_campaign=tlcoronavirus20\&utm_content=120 403755. (erişim 14.08.2020)

Baltacıoğlu, İ. Hakkı. Talim ve Terbiyede İnkılâp. İstanbul: Kanaat Kitabevi, 1927.

Barr, Robert B. ve John Tagg. "From Teaching to Learning: A New Paradigm for Undergraduate Education”. Change: The Magazine of Higher Learning. 27/6 (1995):12-26.

https://naspa.tandfonline.com/doi/abs/10.1080/00091383.1995.10544672?jou rnalCode $=\mathrm{vchn20 \# .X5R2my1h0Wo.} \mathrm{(erişim} \mathrm{10.08.2018).}$

Bursalığlu, Z. Okul Yönetiminde Yeni Yapı ve Davranış. Ankara: Personel Eğitim Merkezi, 1994.

Bolman, Lee G. ve Deal Terrence E. Modern Approaches to Understanding and Managing Organizations. Oxford: Jossey Bass Pub., 1990.

Cin, Firdevs Melis, Ecem Karlıdağ Dennis ve Zeynep Temiz. "Capabilities-Based Gender Equality Analysis of Educational Policy-Making and Reform in Turkey". Gender and Education. 32/2 (2020): 244-261. https://www.tandf online.com/doi/pdf/10.1080/09540253.2018.1484429. (erişim 20.09.2020).

Clune, William H. ve Paule A. White. School-Based Management. CPRE Research Report Series, 1988.

Cüceloğlu, Doğan ve İrfan Erdoğan. Öğretmen Olmak: Bir Can'a Dokunmak. İstanbul: Final Kültür Sanat Yayınları, 2014.

Erdoğan, İrfan. Eğitimde Değisşim Yönetimi. Ankara: Pegem Yayınları, 2012.

Güven, İsmail. "The 4+ 4+ 4 School Reform Bill and the Fatih Project: Is It a Reform?”. İlköğretim Online. 11/3 (2012): 556-577. (erişim 16.09.2020)

Huber, Stephan Gerhard ve Christoph Helm. "COVID-19 and Schooling: Evaluation, Assessment and Accountability in Times of Crises: Reacting Quickly to Explore Key Issues for Policy, Practice and Research with the School Barometer". Educational Assessment, Evaluation and Accountability, 
32 (2020): 1-34. https://link.springer.com/article/10.1007/s11092-020-09322y.(erişim 15.06.2020)

Kaden, Ute. "COVID-19 School Closure-Related Changes to the Professional Life of A K-12 Teacher". Education Sciences. 10/6 (2020): 165. https://www.mdpi.com/2227-7102/10/6/165. (erişim 03.07.2020).

Mason Williams, Loretta, Michael Rosenberg, Lois Kimmel ve Paul Sindelar. "Addressing Shortages of Educators in An Uncertain COVID-19 Landscape: Viewing Teacher Candidates as Assets". Center on Great Teachers and Leaders. 2020. https://eric.ed.gov/?id=ED607020. (erişim 20.08.2020)

Maldonado, Joana ve Kristof De Witte. "The Effect of School Closures on Standardised Student Test". FEB Research Report Department of Economics 2020. https://lirias.kuleuven.be/3189074?limo=0. (erişim 16.09.2020).

Moss, G., R. Allen, A. Bradbury, S. Duncan, S. Harmey, ve R. Levy, "Primary Teachers' Experience of the COVID-19 Lockdown: Eight Key Messages for Policymakers Going Forward”. London: UCL Institute of Education, 2020. https://discovery.ucl.ac.uk/id/eprint/10103669/. (erişim 12.07.2020)

Ronan, Kevin ve David Johnston. Promoting Community Resilience in Disasters: The Role for Schools, Youth, and Families. NewYork: Springer Science \& Business Media, 2005.

Teräs, Marko, Juha Suoranta, Hanna Teräs, ve Mark Curcher, "Post-Covid-19 Education and Education Technology 'Solutionism': A Seller's Market". Postdigital Science and Education, 2/3 (2020): 863-878.

UNESCO. "COVID-19 Educational Disruption and Response". Erişim 11 Ağustos, 2020. https://en.unesco.org/covid19/educationresponse.

UNESCO. "How Teachers Are Leading Efforts to Ensure Learning Never Stops during COVID-19 Education Disruption”. Erişim 26 Eylül, 2020. https://en.unesco.org/news/how-teachers-are-leading-efforts-ensurelearning-never-stops-during-covid-19-education. 


\title{
New Education System Again
}

\author{
İRFAN ERDOĞAN
}

Abstract: In Turkish Education System, there has not been a fundamental philosophical and structural change for a long time. Under the current context of COVID-19 outbreak, there has been nationwide school closures all around the world, and a new era in education has begun. In this period, education is expected to go through an inevitable structural change. In this paper, accordingly, we proposed to minimize and restrict the powers hold by National Ministry of Education (NME). Hence, Education and Training Policies Board would be the highest and influential authority in policy making while NME would function as an executive unit. Meanwhile, local authorities would be supported to make decisions to meet local needs. Aside the structural change, Education is in a need to obtain a new philosophical stance. Accordingly, as the main pillars of education we need to redefine the notions of school, teacher and student. In this respect, we can define school as the institution for supporting learning, teacher as a guide for students, and student as an ultimate learner who can learn from anyone at anywhere. Hence, while schools and teachers would act the roles of providing learning opportunities and regulating learning; students would perceive themselves not as instructed individuals but as autonomous learners. Therefore, in the future, schools, teachers and students would be resilient to unforeseen negative social events similar to the current pandemic conditions.

Keywords: National Ministry of Education, Education and Training Policies Board, New Education 